DISTRIBUTION SHEET

\begin{tabular}{|c|c|c|c|c|c|}
\hline \multirow{2}{*}{$\begin{array}{l}\text { To } \\
\text { Distribution }\end{array}$} & \multirow{2}{*}{\multicolumn{3}{|c|}{$\begin{array}{l}\text { From } \\
\text { B. L. Aftanas }\end{array}$}} & \multicolumn{2}{|l|}{ Page 1 of 1} \\
\hline & & & & \multicolumn{2}{|c|}{ Date $9 / 9 / 94$} \\
\hline \multicolumn{4}{|l|}{ Project Title/Work Order } & \multicolumn{2}{|c|}{ EDT No. 608783} \\
\hline \multicolumn{4}{|c|}{$\begin{array}{l}\text { Bolting Sequence for Attaching the Container to the Strong-back } \\
\text { for } 2415 Y 101 \text {. }\end{array}$} & \multicolumn{2}{|l|}{ ECN No. NA } \\
\hline Name & MSIN & $\begin{array}{c}\text { Text } \\
\text { With All } \\
\text { Attach. }\end{array}$ & Text Only & $\begin{array}{l}\text { Attach./ } \\
\text { Appendix } \\
\text { Only }\end{array}$ & $\begin{array}{c}\text { EDT/ECN } \\
\text { Only }\end{array}$ \\
\hline
\end{tabular}

B. L. Aftanas

J. R. Ammerman

J. R. Biggs

S. R. Crow

J. V. Egger

D. S. Gleason

C. E. Hanson

J. P. Hauptmann

L. S. Krogsrud

J. W. Lentsch

R. L. Jorissen

T. C. Mackey

J. C. Mast

M. L. McElroy

G. E. McPherson

R. E. Mendoza

D. P. Niebuhr

M. J. Ostrom

R. B. Pan

T. K. Peterson

J. J. Sisk

R. G. Sobocinski

Project Files

Central Files

O.S.T.I.

$\begin{array}{ll}\text { H5-70 } & X \\ \text { T2-08 } & X \\ \text { T4-01 } & X \\ \text { G2-03 } & X \\ \text { S2-03 } & X \\ \text { S3-15 } & X \\ \text { H5-09 } & X \\ \text { S2-03 } & X \\ \text { R3-08 } & X \\ \text { R2-78 } & X \\ \text { H5-53 } & X \\ \text { S2-03 } & X \\ \text { H5-09 } & X \\ \text { S1-57 } & X \\ \text { T4-10 } & X \\ \text { R } 1-51 & X \\ \text { T4-01 } & X \\ \text { H5-70 } & X \\ \text { H5-53 } & X \\ \text { S2-03 } & X \\ \text { S2-03 } & X \\ \text { H5-09 } & X \\ \text { H5-09 } & X \\ & \\ \text { L8-00 } & X \\ \text { L8-07 } & X\end{array}$




\section{DISCLAIMER}

Portions of this document may be illegible in electronic image products. Images are produced from the best available original document. 


\begin{tabular}{|l|l|}
$\begin{array}{l}\text { 2. To: (Receiving organization) } \\
\text { See Distribution List }\end{array}$ & $\begin{array}{l}\text { 3. From: (originating Organization) } \\
\text { Engineering Services }\end{array}$ \\
\hline 5. Proj./Prog./Dept./Div.: & 6. Cog. Engr.: \\
241-SY-101 & T. C. Mackey \\
\hline
\end{tabular}

8. Originator Remarks:

The attached Bolting Sequence for Attaching the Container to the Strong-Back for 241SY101 is routed for your approval.
4. Related EDT No.:

NA

7. Purchase Order No.:

NA

9. Equip./Component No.: NA

10. System/Bldg./Facility: 241-SY-101

11. Receiver Remarks:

NA

13. Permit/Permit Application No.: NA

14. Required Response Date: ASAP

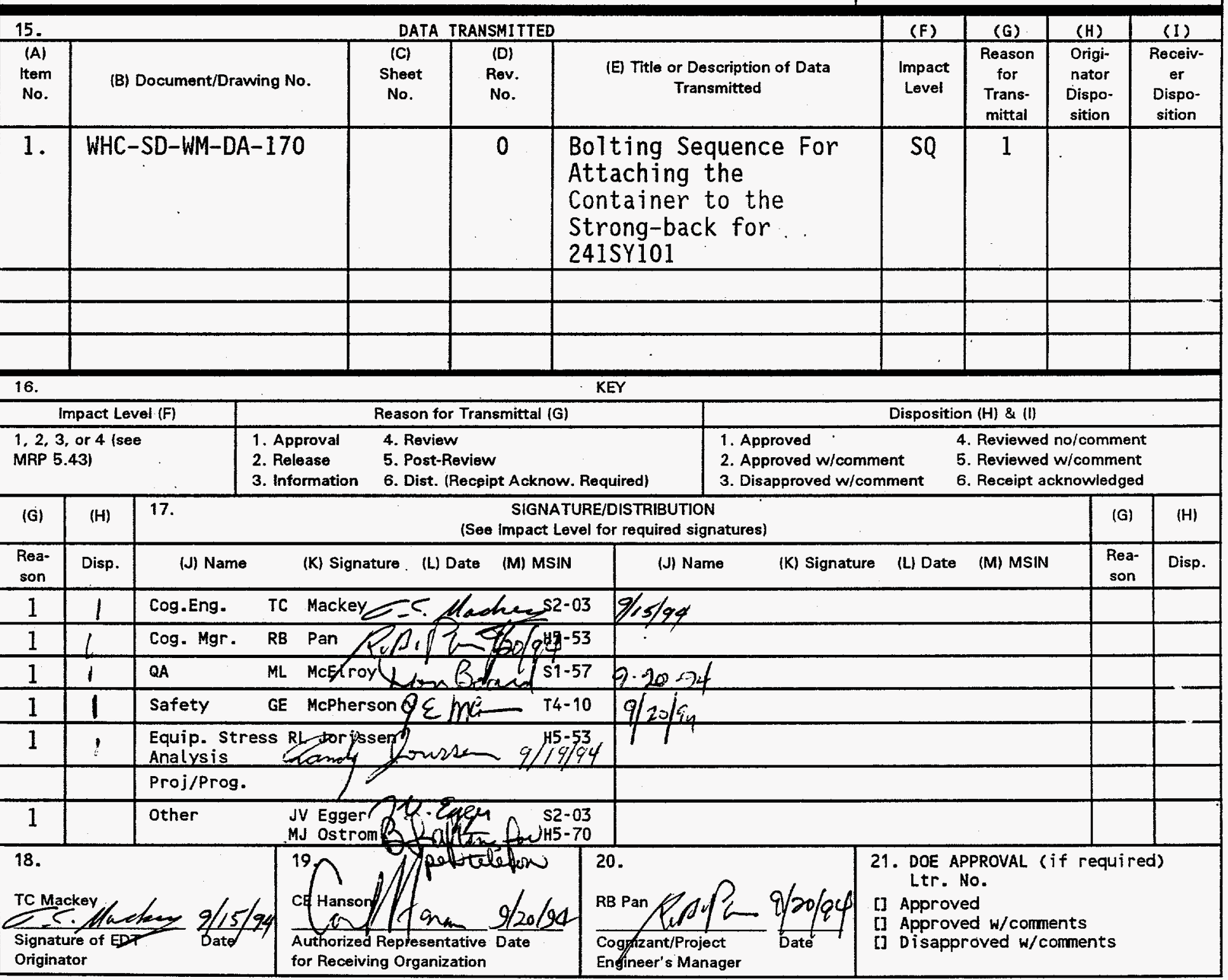




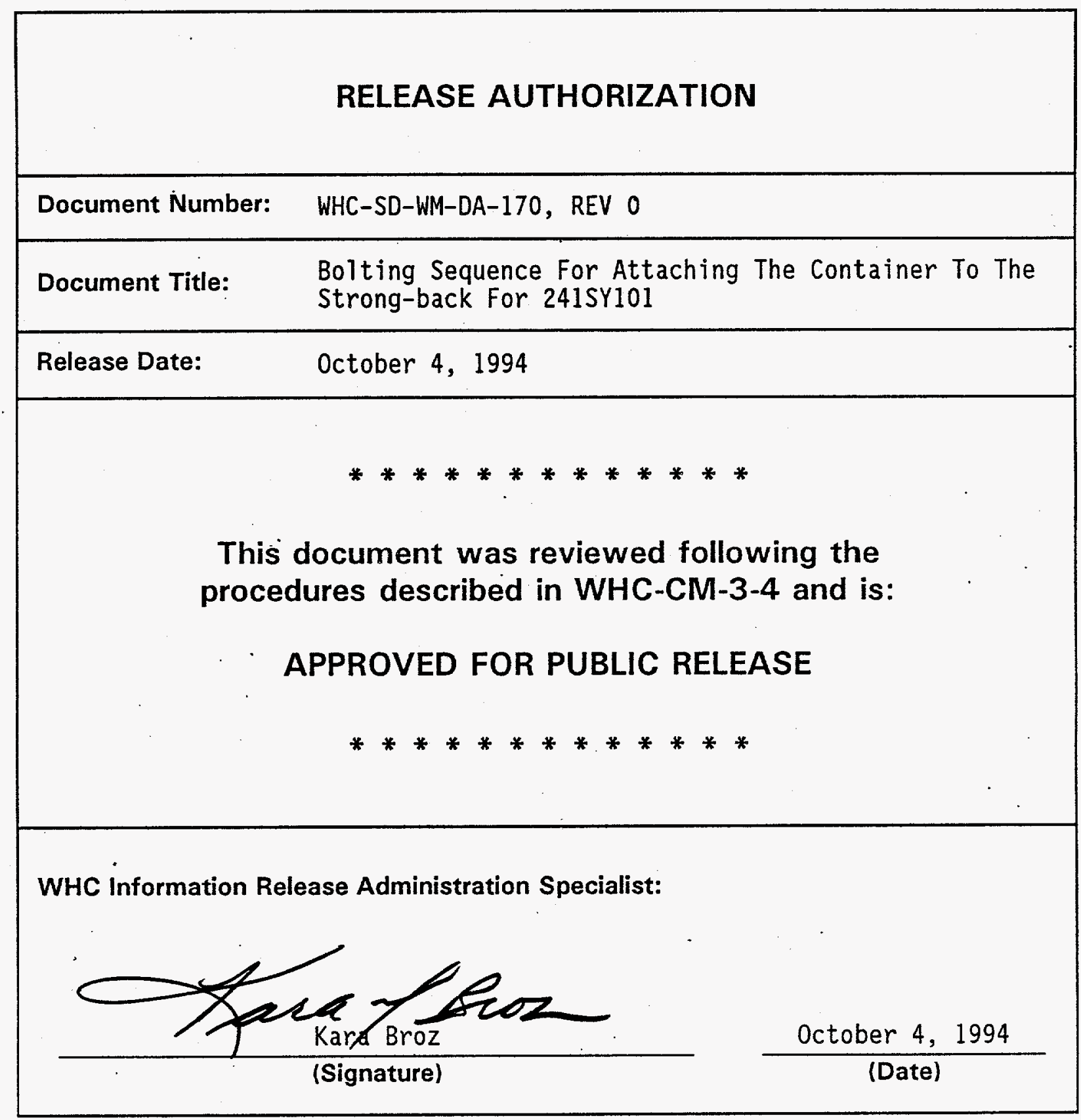


2. Title

Bolting Sequence For Attaching The Container To The Strong-back For 241SY101.

5. Key Words

bolting sequence

container

strong-back

241SY101

mitigation

test pump removal

3. Number

WHC-SD-WM-DA-170

4. Rev No.

\section{Abstract}

This bolting sequence is for attaching the container to the strong-back for 241-SY101. It is routed for your approval.

\section{APPROVED FOR PUBLIC RELEASE}

8. MURPOSE AND USE OF DOCUMENT - This document was prepared ror use withim the U.S. Department of Energy and its contractoos? It is to be used boly to perform, direct, or integoere work under U.S. Department of Energy contracts. This doctinent is not approved for public release Until reviewed.

PATENT STATUS - This document 2 ary, since it is transmitted in advance of patent clearance is made aveilable in confidence solely for use in performance of work undem contracts with the U.S. Department of Energy. This document is not to be publ ished nor its contents otnerwise disseminated or used for purposeonother than specified ibove before patent approval for such release or on has beep secured, upon request, from the Patent Counsel, U.S. Departmerr onergy Field office, Richland, WA.

DISCLAIMER - This report was prepared as an account of work sponsored by an agency of the United States Government. Neither the United States Government nor any agency thereof, nor any of their employees, nor any of their contractors, subcontractors or their employees, makes any warranty, express or implied, or assumes any legal liability or responsibility for the accuracy, completeness, or any third party's use or the results of such use of any information, apparatus, product, or process disclosed, or represents that $\mathrm{jts}$ use would not infringe privately owned rights. Reference herein to any specific commercial product, process, or service by trade name, trademark, manufacturer, or otherwise, does not necessarily constitute or imply its endorsement, recommendation, or favoring by the United States Government or any agency thereof or its contractors or subcontractors. The views and opinions of authors expressed herein do not necessarily state or reflect those of the United States Government or any agency thereof.

9. Impact Level $\mathrm{SQ}$

10. RELEASE STAMP
Name: T. C. Mackey

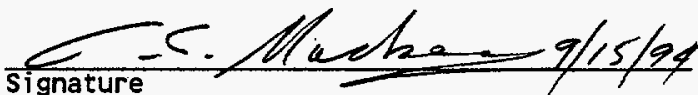

Organization/Charge Code 
WHC-SD-WM-DA-170

Rev. 0

\title{
BOLTING SEQUENCE
}

FOR

\section{ATTACHING THE CONTAINER TO THE STRONG-BACK}

FOR 241SY101

\author{
September 1994
}

PREPARED BY:

T. C. Mackey, Princip Engineer

Equipment Stress Analysis

PREPARED BY:

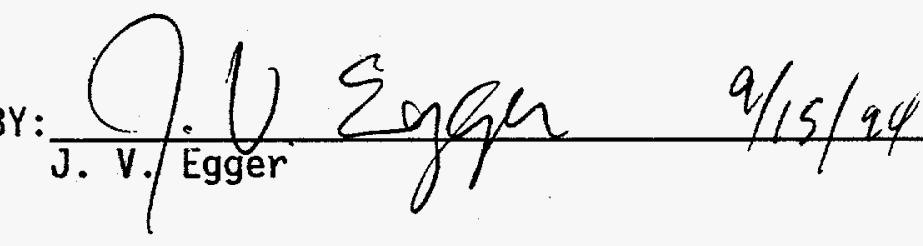

REVIEWED BY:

R. L. Jorissen, Principal Engineer

Equipment Stress Analysis

aPPRoved BY: Papeq $q / 20 / \varepsilon \psi$

R.. B. Pan, Manager

Equipment Stress Analysis

Westinghouse Hanford Company

Hanford Operations and Engineering Contractor

for the

U. S. Department of Energy 
WHC-SD-WM-DA-170

Rev. 0

DESIGN VERIFICATION METHOD

The need for design verification has been reviewed with the method selected as indicated below: (ESR/Work P1an \# NA / WP-23480-309).

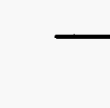

$x$

-
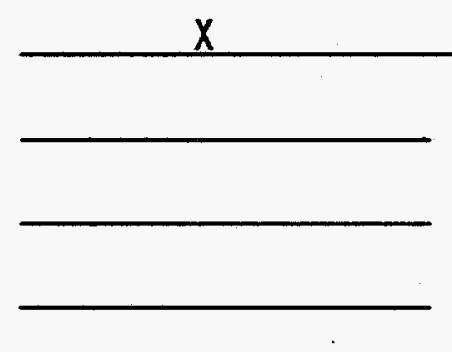

SD \#WHC-SD-WM-DA-170

ECN \#

$D W G(S) \#$

\author{
Independent Review \\ Alternate Calculations \\ Qualification Testing \\ Formal Design Review
}

R. B. Pan P D.

Cognizant/Project/Design Manager 


\section{INDEPENDENT REVIEW CHECKLIST}

Document Reviewed Bolting Sequence - Container to Strong-back

Author T.C. Mackey / J. V. Egger

Yes No N/A

$\infty$ ( ) ( ) Problem completely defined.

( ) ( ) (W). Are computer analysis applications documented in the report per EP 2.1? (code, version, hardware, input, output files)

( ) ( ) (X) Is the software verification documentation either referenced or included in the report?

( ) ( ) ( ()$_{1}$ Computer code error reports reviewed for impact if any.

( ) ( ) (A) Data used in calculations explicitly stated in document.

( ) ( ) (1) Data checked for consistency with original source information as applicable.

( ) ( ) (X) Mathematical derivations checked, including dimensional consistency of results.

( ) ( ) ( Models appropriate and used within range of validity or use outside range of established validity justified.

( ) ( ) ( $y$ Hand calculations checked for errors.

( ) ( ) ( $\rtimes$ Code run streams correct and consistent with analysis documentation.

( ) ( ) (メ) Acceptability limits on analytical results application and supported. Limits checked against sources.

( ) ( ) (y) Safety margins consistent with good engineering practices.

$(\infty)$ ( ) ( ) Conclusions consistent with analytical results and application limits.

( $)$ ( ) ( ) Results and conclusions address all points required in the problem statement.

B. L. Jorissen

Reviewer
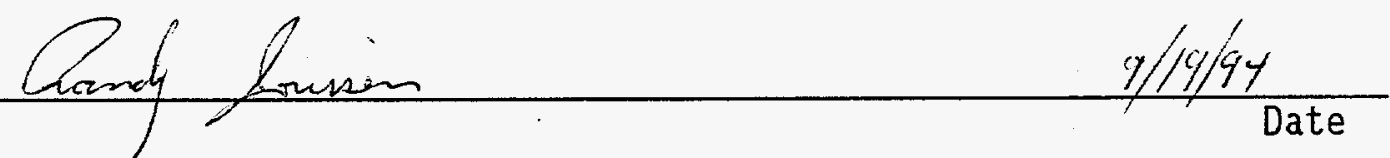
1.0 Introduction ................. 1

2.0 Summary of Results ................... 1

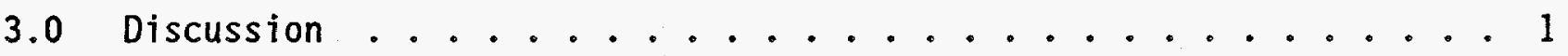

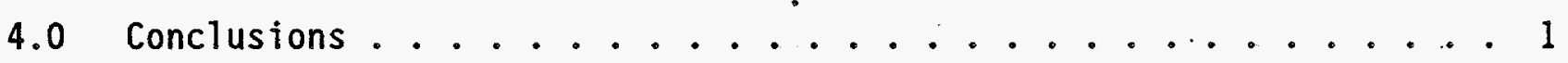

5.0 Recommendations ................ 2

6.0. References ................. 4 
WHC-SD-WM-DA-170

Rev. 0

\section{BOLTING SEQUENCE FOR ATTACHING \\ THE CONTAINER TO THE STRONG-BACK}

\subsection{INTRODUCTION}

This supporting document includes information for the proper bolting sequence for attaching the container to the strong-back. The design of the container and strong-back is found in supporting document WHC-SD-WM-DA-165 (WHC 1994a) and is in accordance with Standard Arch-Civil Design Criteria, Design Loads for Facilities (SDC 4.1) Safety Class 3.

\subsection{SUMMARY OF RESULTS}

The following bolting sequence has been found, through field testing, to be the most effective method of attaching the container (WHC 1994d) to the strong-back (WHC 1994b). The diameter, length, and type of bolts required are calculated in WHC-SD-WM-DA-165 (WHC 1994a) and are shown in the drawings of WHC 1994b and WHC 1994c. This supporting document summarizes the bolt requirements and provides the fit up and bolting sequence required to most effectively attach the container to the strong-back.

\subsection{DISCUSSION}

During the fabrication process, the container attachment lugs are placed flush up against the strong-back attachment assemblies. After the container attachment lugs are matched to the strong-back attachment assemblies, the container attachment lug is welded into position. Finally, the container attachment lug is match drilled to the strong-back attachment assembly. This fabrication process ensures that a close fit up can be achieved between the container, the attachment assemblies, and the strong-back.

After the containers were matched to the strong-back, the containers were removed and painted. In order to effect the same match of the container to the attachment assemblies and strong-back, the container must be relocated to the matched position. The bottom of the attachment assemblies have slotted holes which allows the assembly to slide laterally during fit up.

\subsection{CONCLUSIONS}

This bolting sequence has been found to be structurally effective for attaching the container to the strong-back. Adherence to this supporting document for field installation should greatly reduce or el iminate field fit up and bolting problems. 


\subsection{RECOMMENDATIONS}

The following recommendations shall be followed to ensure that the container is properly bolted to the strong-back:

Prior to installing any bolts, verify that the threaded portion of the bolts and nuts are clean and undamaged. Do not add lubricant of any type to the bolt or nut thread. The only lubricant that may be on the nut or bolt thread is the trace of machine oil that was applied at the factory during fabrication.

Never reuse bolts that have been previously torqued. Any bolts that have been torqued should be identified and removed from service.

Align the container, attachment assemblies and strong-back;

- The strong-back has four bearing blocks, two per side and approximately 24 feet apart, that are designed to support the weight of the container. The container attachment lugs (see Figure 1) should rest on the four bearing blocks. Carefully place the container into the strong-back. Insure that the container support is properly positioned on the deck of the hydraulic trailer.

- Place all four of the attachment assemblies on the strong-back. Verify that the bolts are $A 325$, and verify the length and location of the bolts as shown in Figure 2. Loosely install all the 1" bolts and washers so that the attachment assemblies are free to slide lateraliy (see Figure 3a).

- Re-position the container as necessary to best match up to all four of the attachment assemblies. Some differences between the container, attachment assemblies, and strong-back are inevitable however no more than about $1 / 4^{\prime \prime}$ gap between mating surfaces should be present. This gap will become less as the bolts are tightened.

\section{Install bolts}

Note that "Snug tight" is defined as "the full effort of a man using an ordinary spud wrench". Therefore, do not use a breaker bar or excessive force to tighten the bolt. Only use full effort and an ordinary wrench to snug up the bolt.

- Install, to finger tight condition, all of the $21 / 2$ " bolts, nuts and washers (see Figure 3b). Do not use a wrench to tighten the bolts at this time.

- Install, to finger tight condition, all of the 1" bolts and washers. Do not use a wrench to tighten the bolts at this time.

- Determine which attachment assembly has the largest gap between the vertical face of the attachment assembly and the face of the container attachment lug. Proceed to tighten, only to a "snug tight" condition, the $21 / 2$ " bolt at this attachment assembly. 
- Document the length of the $21 / 2 "$ bolt with a micrometer. If this can not be done then document the amount of gap between the vertical face of the attachment assembly and the face of the container attachment lug. The bolt length or gap will.be checked after tightening the 1" bolts at the bottom of the assembly.

- Determine the next attachment assembly that has the largest gap, as described above, and tighten the $21 / 2^{\prime \prime}$ bolt as described above. Continue this process until all four of the $21 / 2$ " bolts are "snug tight".

- Determine which attachment assembiy has the largest gap between the horizontal face of the attachment assembly and the horizontal face of the strong-back. Proceed to tighten, only to a "snug tight" condition, the 1 " bolts at this attachment assembly. Sequence bolt tightening as "tightening shall progress systematically from the most rigid part of the joint to its free edges".

- Document the length of the $21 / 2^{\prime \prime}$ bolt with a micrometer. If this cannot be done then document the amount of gap between the vertical face of the attachment assembly and the face of the container attachment lug. Compare the bolt length or gap measurement with the measurement taken

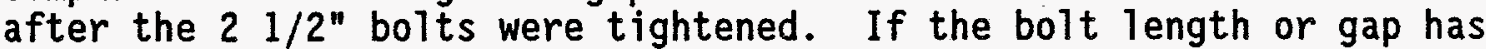
increase more than .0833" then contact the engineer for further direction. If the bolt length or gap is less than .0833" then the bolted connection is adequate.

- Determine the next attachment assembly that has the largest gap, as described above, and tighten the 1 " bolts as described above. Continue this process until al1 twenty four of the 1" bolts are "snug tight". 
WHC-SD-WM-DA-170

Rev. 0

\subsection{REFERENCES}

AISC, 1989, Manual of Steel Construction, 9th Edition, American Institute of Steel Construction, Chicago, Illinois.

SDC 4.1, Rev. 12, 1989, Standard Arch-Civil Design Criteria, Westinghouse. Hanford Company, Richland, Washington, 1993.

WHC 1994a, Structural Analysis of the Equipment Removal System for Tank 241SY101, WHC-SD-WM-DA-165, Westinghouse Hanford Company, Rich7and, Washington, 1994.

WHC 1994b, Strongback, drawing H-2-83736, Rev. 0, Westinghouse Hanford Company, Richland, Washington, 1994.

WHC 1994c, Hydrogen Mixer Pump Storage Transport Assemb7y Arrangement, H-2-83750, Rev. 0, Westinghouse Hanford Company, Richland, Washington, 1994.

WHC 1994d, Hydrogen Mixer Pump Storage Container, drawing H-2-83734, Westinghouse Hanford Company, Richland, Washington, 1994. 
WHC-SD-WM-DA-170

Rev. 0

\section{Figure 1 Container Attachment Lugs}

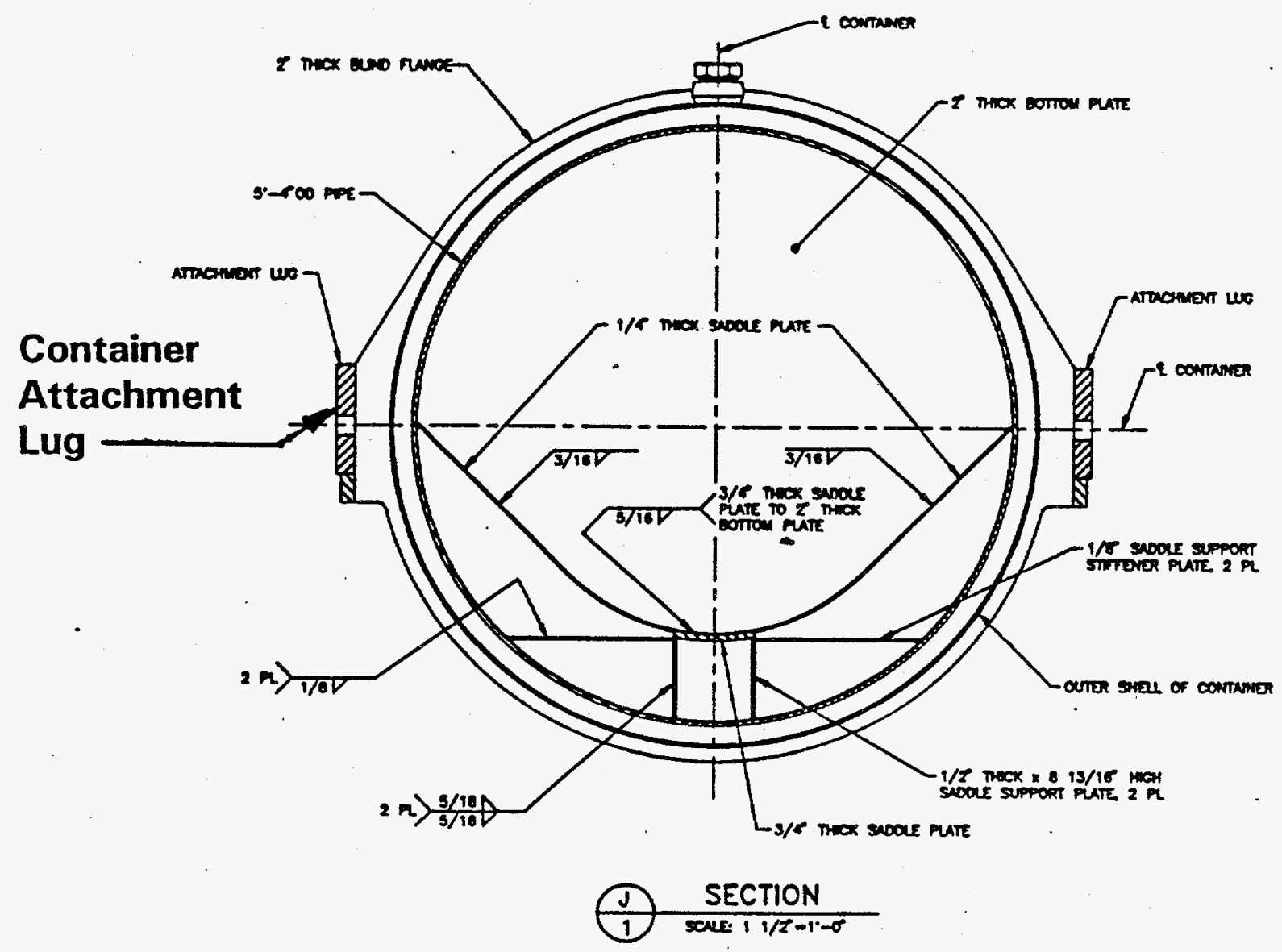

For Information Only

From $\mathrm{H}-2-83734$ sheet 7 


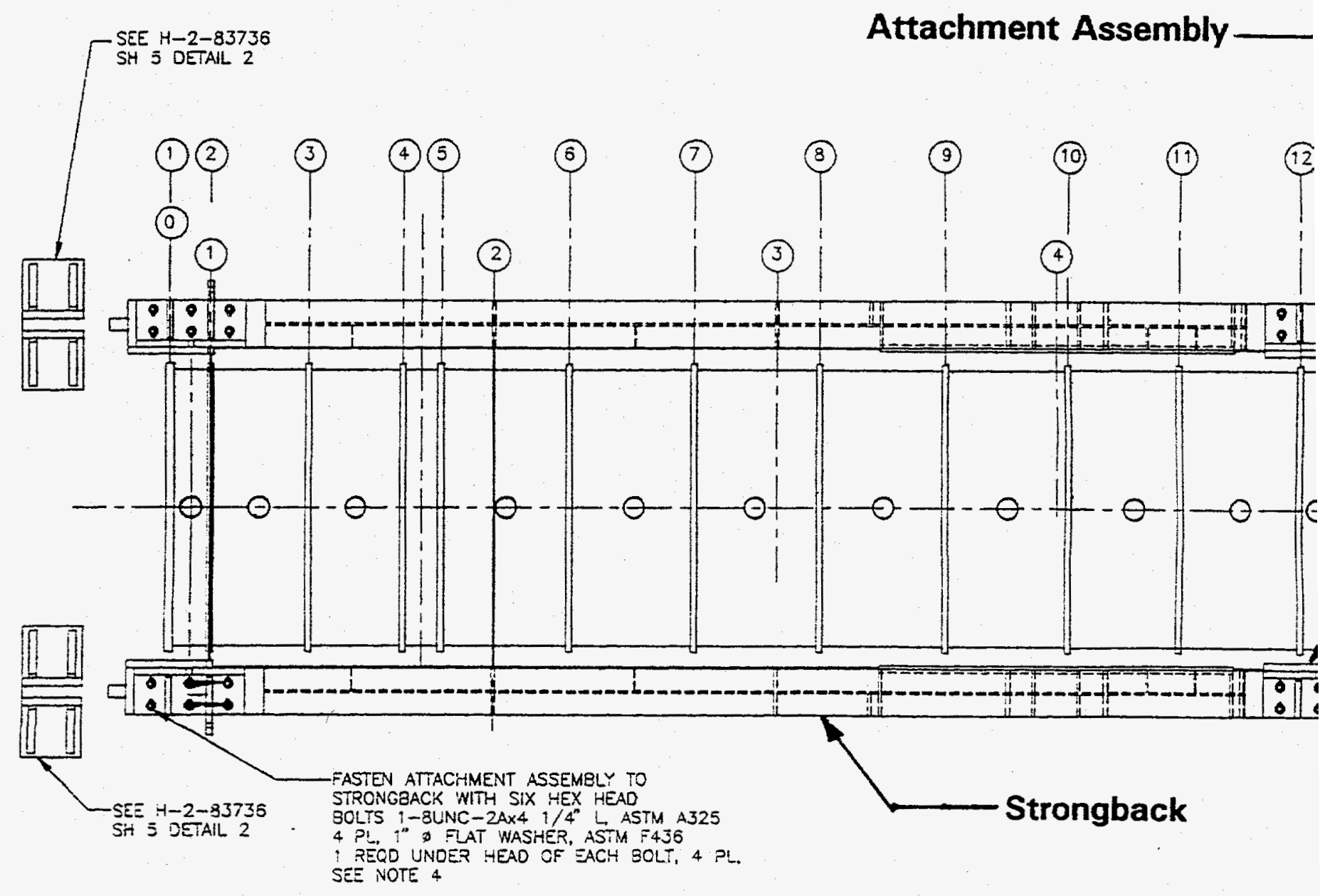


WHC-SD-WM-DA-170

Rev. 0

Figure 2 Strong-back and Container

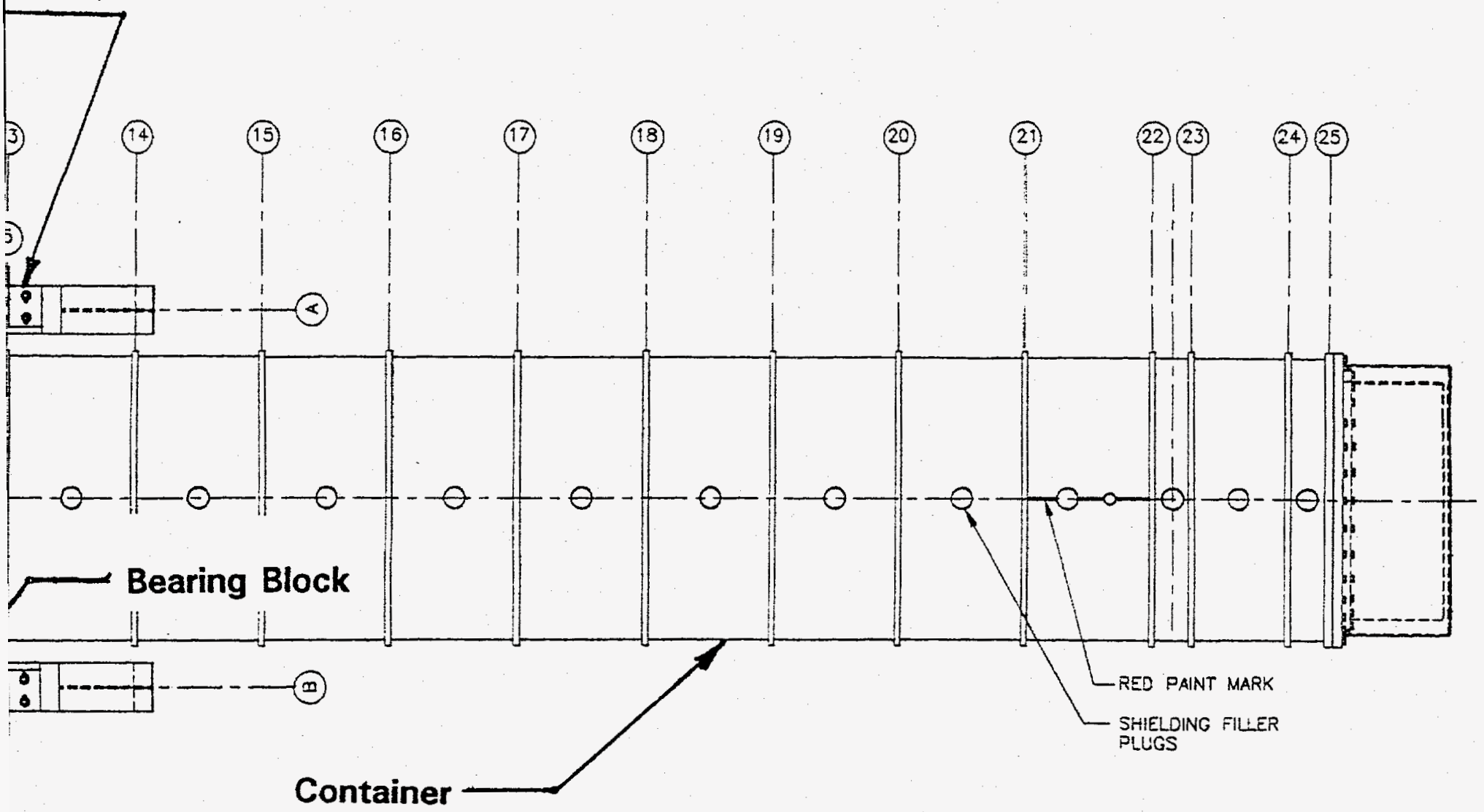

PLAN (HYCROGEN MIXER PUMP CONTAINER)

SCALE: $: 1 / 2^{*}=1^{\prime}-0^{\prime \prime}$ 
Figure 3a Attachment Assembly Plan View

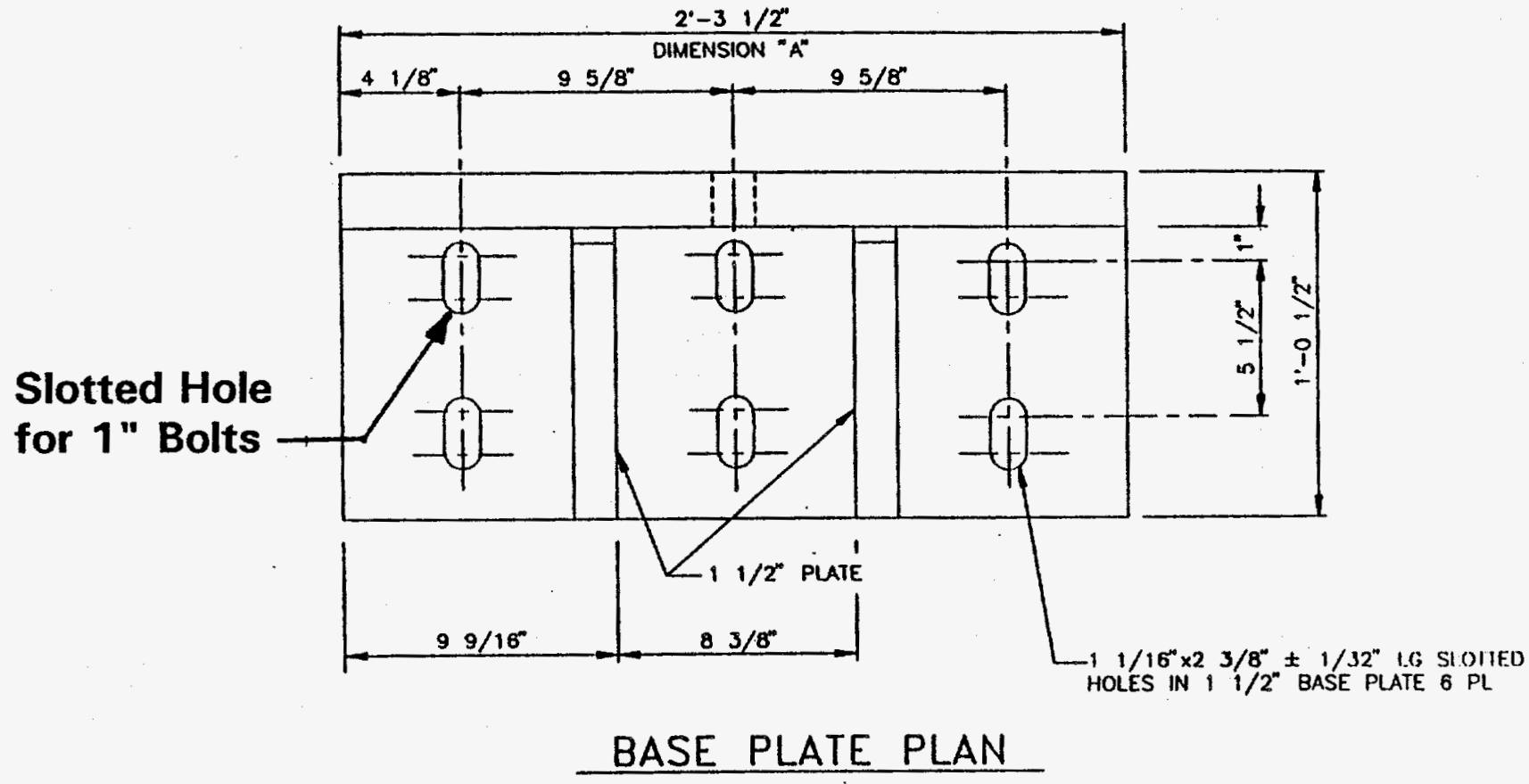

Figure 3b Attachment Assembly Side View

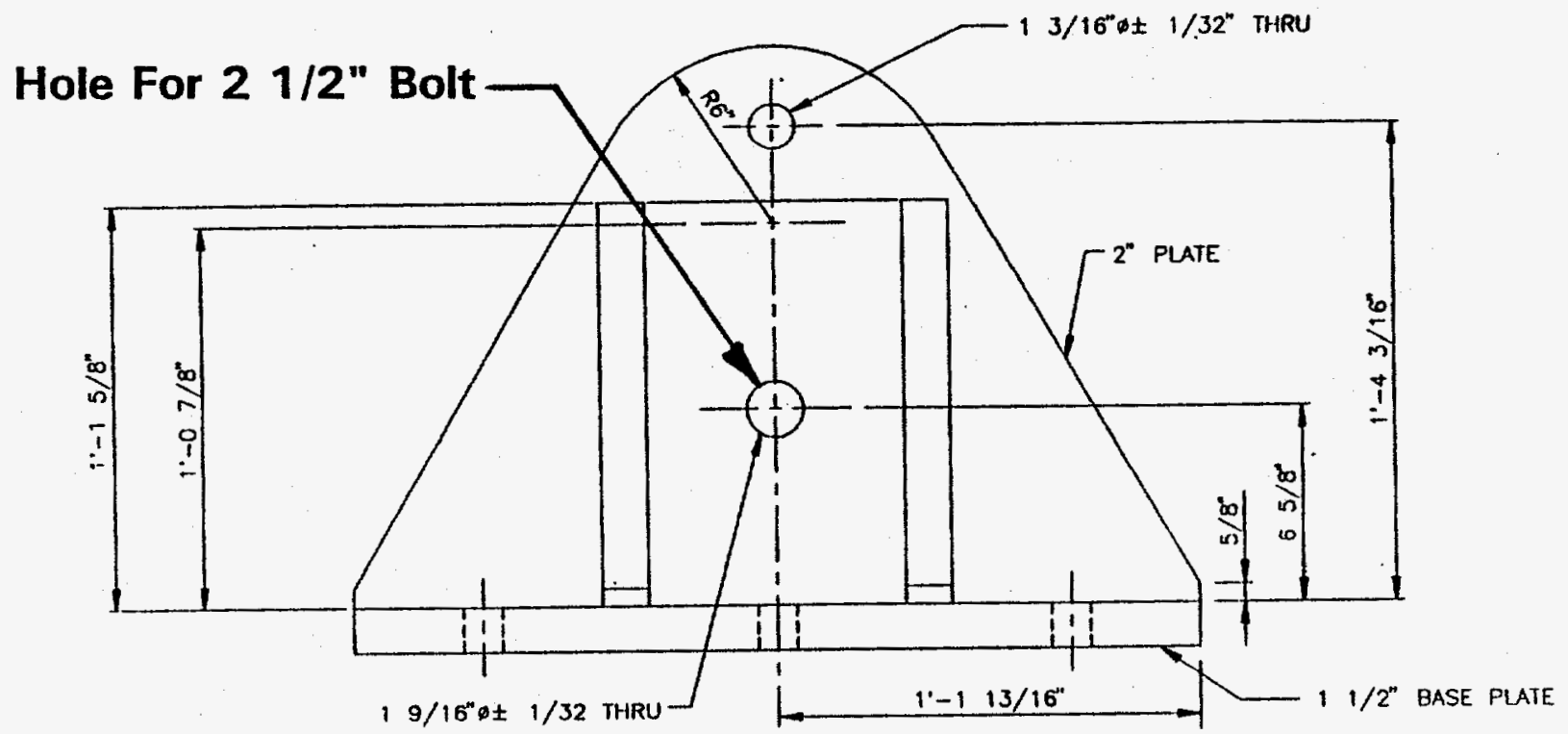

FRONT VIEW

For Information on $7 y$

From $\mathrm{H}-2-83736$ sheet 5 